\title{
IDIOMS OF PROTEST AND RESISTANCE: ASSERTION OF SUBJECTIVITY AND IDENTITY FORMATION IN DALIT WRITINGS
}

\author{
Dr. Preeti Oza \\ St. Andrew"s College \\ University of Mumbai \\ preetioza1@gmail.com
}

Language is a very distinctive aspect of marginal writings like African American, Dalit writings, feminist writings etc. They prefer to use their day-to-day spoken languages to those of the standard languages of the mainstream literature. As the experiences of these writers are so unique, that even the standard languages lack the required vocabulary to make them explicit to the general readers. They tend to express their unique experiences of exploitation in their own languages as it can only afford to give proper flavor and touch to such experiences. The use of standard language would otherwise prove an exercise in futility to concretize the true feelings and experiences of these writings. As the spoken language dominates in these writings, the writers enjoy freedom with the rules of grammar.

To understand the nuances of language in use like idioms and narratives, and for the sake of convenience and better scrutiny, this literature can be grouped under two main heads - The Content Aspects of Protest writings and the Expressive Aspects of Protest writings. The social norms like caste, class, race, religion, and gender fall under the Content Aspects of Protest writings. For example, on the basis of these social norms, African Americans and Dalits were being discriminated and exploited by the dominant groups of their societies. So the autobiographies of these oppressed people are the accounts of how they were exploited at the brutal hands of various social and political institutions like slavery, untouchability, patriarchy, education, family, religion, law, culture and literature and how they came to be realized their oppression, and also how they revolted against their oppressors and their institutions of oppression. Expressive Aspects of Protest writings include the use of Dalit and Black vernaculars and also the narrative techniques used by them in their writings. A close analysis of these writings shows that they are interspersed with a variety of vocabulary items, which are unknown to the mainstream literature.

This paper will attempt to make a typological display of various distinctive figures of Dalit subaltern consciousness. The inner quest of identity, the cultural denunciations of the iniquitous Hindu dispensation and the social struggles to assert one's human dignity take various forms according to the will, vision and capacity of each writer. Nonetheless, some recurrent types of idioms can be defined. These self-narratives bear direct testimony to the inalienable creative potentialities of the human agent. These are some of the idioms of protest and resistance, which will provide assertion of subjectivity and identity formation in Dalit writings.

Mass Literature, Literature of Action, Literature of Protest and Marginalized Literature are different names of this emerging genre of literature which has blossomed world over out of socio-political and cultural transformation. Besides a strong tendency towards self-representation has been rising among those discriminated against for centuries. Bill Ashcroft aptly writes,

,"Marginality becomes an unprecedented source of creative energy". The literature by the Burakumin of Japan, Backjeong of Korea, Midgan of Somalia, Dalits of India are living instances of this phenomenon. They explore the underbelly of the society in a diction that subverts the middle-class concepts of linguistic etiquette and standard. ( Ashcroft 1998)

Dalit writing has been described as one of the manifestations of postmodernism in Indian literature. However, the acquisition of the postmodernist idiom, modes and attitude have not been uniform in Dalit Literature. A general presentation of the social, literary phenomenon of the "Dalit literature" -- the literature of the oppressed -- is firstly required to realize the specificity of that significant trend in the recent literature (since the sixties) in India. The readers, scholarly as well as casual heard a new language, a new direct, accusatory, angry and analytical voice, and a literary production which dared to challenge the century-old myths, traditions, and practices.

For example, Namdeo Dhasal"s iconic poem in Dilip Chitre"s translation: Cruelty

I am a venereal sore in the private part of the language.

The living spirit looking out

of hundreds of thousands of sad, pitiful eyes Has shaken me.

I am broken by the revolt exploding inside me. There"sno moonlightanywhere;

There"s no water anywhere.

A rabid fox is tearing off my flesh with its teeth; And a terrible venom-like cruelty 


\section{GAP BODHI TARU -}

\section{An International Peer-Reviewed \\ Open Access Journal of Humanities}

Spreads out from my monkey-bone.

(Chitre 2007)

Here the words are full of raw fire. One can see a fury of degradation, obscenity, filth, rage, and horror. No attempt to disguise the raw and hurt emotions is ever made.

These characteristic features form a set of aesthetic norms that help the marginal writings like African American and Dalit writers to construct their „psycho-social self" in their writings. A close evaluation of African American and Dalit autobiographies shows that the psycho-social self of their authors was constantly in conflict with brutal social, political and religious institutions of their times. It is so because this „self" was a kind of threat to the smooth functioning of these institutions. Therefore, these institutions of established classes always tried to create as many obstacles as possible in the path of the "self" of their victims and attempted to deviate them away from positive growth.

The distinctiveness of Dalit literature lies in its authentic unity of language and content. In it, the disillusionment and disgust of young Dalits, often accompanied by a desire for revenge, come alive. It revives the memory of the pain and suffering of past generations. It confronts centuries of hypocrisy, deceit, and violence sustained in the name of tradition". 'The writings of Dalit scholars also contain powerful denunciations of and fierce attacks on the caste system and on Brahmanical Hinduism. It has been pointed out that the Dalit Sahitya is considered to be a unique genre of modern Indian literature. For now, untouchables themselves using the traditionally-denied weapon of literacy, are exposing the conditions under which they have lived as well as directly rebelling „vidroha' against the Hindu institution which has assured their perpetual subordination to the Vain order.' (Manohar and Rohini Mokashi-Punekar, 2005)

In the initial phase of Dalit literature, the mainstream literary critics questioned the very basis of Dalit literature. They asked in all seriousness: Can Dalits write literature? Can Dalit be subject of literature? They attacked Dalit literature saying that the dirty experiences of Dalit life would spoil the literary mainstream. Their contention was that Dalit literature is not literature. According to them, "It was the drainage of dirty water;" it was slang literature. It had to be stopped otherwise it would harm the religious feelings of the higher castes.

For thousands of years, Dalits politely served the high caste society. It was the destiny of Dalit people. They never revolted against God, religion and social structure. They believe that this was the way of life for them. Anguish against mainstream religion, culture, divine laws reflects constantly in Dalit writings. Jyoti Lanjewar, a Marathi Dalit woman writer, expresses with a roaring voice,

"Begging won"t get anything here Not sympathy, not love,

A suit in court wins injustice, Tears are of no value, Getting water is a struggle,

Wrapping yourself in smoke from a dead fire won" $t$ work,

You have to plant the cinder of revolt in your own body". (Joti Lanjewar)

(Anand, Mulkra 1992)

Their suffering is not just the suffering of the individual, and there is nothing romantic about it. Their problem is neither ideological nor philosophical. They do not seek poetic beauty. Similes, metaphors, and symbols are not important. The reality of their life is too hideously shocking, beyond the capacity of fantasy or imagination. Their tragedy is universal, trampling them down and disfiguring their humanity. Thus analysis of Dalit poetry mirrors the pathetic life of the ostracized in name of caste. It is observed that poets and authors of Dalit literature have used the power of language to express their feeling of being beleaguered. Dalit poetry thus became an academic stance of the poets that aim to change the fate of the suppressed through their writing. Anna Bhau Sathe gave a clarion call to all Dalits to change their fate in the following words:

Take a Hammer to change the world So saying went Bhimrao!

He visualized the picture of the society devoid of exploitation and their protest would lead to:

Sitting on the chariot of unity Let us go forward

To break the chains of class and caste Hold to the name of Bhim!

( Sathe 1992)

In the poem of J.V Pawar titled „Birds in Prison," the persona of the poem opens up his heart that is filled with anger and frustration against the age-old system of oppression and conventional beliefs of the caste system.

Shouting slogans to condemn or uphold a blaze of fire marches forth And forest fires take birth in oceans that seek to oppose. What obstacle shall now withhold Our turning volcanic vein by vein digging trenches every inch of the terrain?

( Dangle 1992) 


\section{GAP BODHI TARU -}

\section{An International Peer-Reviewed \\ Open Access Journal of Humanities}

It is seen that through the use of imagery "blaze of fire" the poet tries to assert that as the exploitation of Dalits has reached its heights, the time has come when the Dalits will set a fire in the society that has tortured them. The fire will spread like a wild forest fire reducing into ashes all the forces that obstruct their paths. Arjun Dangle gives a harrowing picture of their wretchedness in a poem entitled 'Chhavni Hilti Ha', ('The Cantonment Has Begun to Shake').

We fought with crows,

Never even giving them the snot from our noses. As we dragged out the Upper Lane's dead cattle, Skinned it neatly

And shared the meat among ourselves, They used to love us then.

We warred with jackals--dogs--vultures--kites Because we ate their share.

( Dangle 1992)

The theoretical variety of revolutionaries cannot even imagine the predicament these wretched people live in. Namdeo Dhasal cries out:

This world's socialism, This world's communism

And all those things of theirs, We have put them to the test And the implication is this-

Only our shadows can cover our own feet ( Dhasal 1975)

For Namdeo Dhasal, it is a prostitute in his poem „Mandakini", who in spite of being an object of carnal love, is still abhorred as she never gets an identity like a wife, and hence, remains without any institutionalized sanctity.

„The relationship of men and women is like that-

Take a few whores; take a few pimps; take a few chewing sticks to clean the Teeth;

And throw them away after use; and then gargle with the holy water of the river"

(Arora, 2009) The soul of poetry is rasa, Dhasal"s poetry also provides rasa, but not the common rasas like Shringar, bhakti, hasya, or Shanta. Quite contrary, he talks about Bibhatsa rasa which is bitter and nauseating in taste. His verses can be categorized under scatological literature. Here are some lines from a poem of Sharan Kumar Limbale: The church bell rang Everyone entered in The ajan heard from mosque Everyone entered in

The bell of the temple rang Some entered in

And some stood out.

In the poem „Pimpamma Yellamma; the poet writes:

"I will quench the thirst of the thirsty, I will feed the hungry

And I will shelter the homeless... The bewildered girl

In a skirt of leafy neem twigs Takes the oath to yellammas..." ( Bhasker T.)

The title shows the shocking impact of the aesthetics which is crooked. The title

„Pimpamma Yellama is a juxtaposition of two seemingly unmatchable and sacrilegious. Yellamma is the name if a local deity, the incarnation of mother goddess but the adjective is pimp+amma sounds abusing, offending and vulgar. But as the poem unfolds, we realize that Yellamma who allows and encourages the prostitution of small Dalit girls called poor devdasis is not worthy of calling a "mother" or a "goddess" therefore „pimpamma yellamma".the local milieu and diction help in understanding the aesthetics of the poem.

The Dalit poet is often accused of sing foul language, that his tone exudes venomous sarcasm, that his ideology is sacrilegious, his muse is loud and verbose and onerous, that he is vengeful and casteist. The diction is unfigurative and coarse and even vulgar. But this is true for every marginal piece of writing across the world. There are always narratives and counter- narratives of exploitation. Hitler"s biography „Mien Kamph" justifying holocaust of the Jews, or Manu justifying oppression of the Shudras and women, some Ku Klux Klan white writer justifying racial superiority of the whites over black or brown or yellow race, some czarist writer justifying terror and exploitation, some pseudo-communist writer advocating curtailment of fundamental human rights and human dignity- are all ab initio unaesthetic works.

\section{CONCLUSION:}

What is so beautiful about Dalit literature is a pertaining question from the mainstream literary people. But if we look within, there is an unmistakable element of fatalism in it as well. They seem to accept this outward ugliness thus conceding in the process a sense of superiority to the aesthetics of the upper-order: it can be summed up in this Abhanga by Chokha

Cane is crooked, but its juice isn "t crooked Why be fooled by outward appearance?

The bow is crooked, but the arrow isn"t crooked, Why be fooled by outward appearance?

The river is twisting, but the water isn"t crooked. Why be fooled by outward appearance? 


\section{GAP BODHI TARU -}

\section{An International Peer-Reviewed \\ Open Access Journal of Humanities}

Chokha is ugly, but his feelings aren"t ugly.

Why be fooled by outward appearance

( Zelliot, 1995)

So when Sharan Kumar Limbale, a famous Dalit writer was asked,

"Which question should be more enhanced in Dalit literature „Art for Art"s sake" or „Art for Life's sake' and why?", ( Bhaumik, 2017) He answered:

“ I would go with „Art for Life"s sake" rather Art for social cause because Dalit literature has its own social responsibilities. The ideology of Art for Art's sake aims to amuse the senses but to expect the same from Dalit literature is utter foolishness. The reader should be inspired and assured after reading a Dalit text whether it is Joothan, Akkarmashi or Karukku. He should feel enlightened and motivated towards the demolition of the unjust social practices. The objective of freedom is far bigger than the objective of achieving aesthetics. Freedom is a revolutionary idea. People have laid their lives to gain freedom but nobody would do the same for the sake of aesthetic pleasure. The desire for liberty may lead to a revolutionary change in our society."

\section{REFERENCES}

Kanaujia Neha, „An interview with Sharan Kumar Limbale“, Research Scholar, ISSN 2320

6101

Anand, Mulk Raj and Zelliot Eleanor (Ed), “An Anthology of Dalit Literature”, 1992, Gyan Publishing House, New Delhi Anand, Mulk Raj, and Eleanor Zelliot. An anthology of Dalit literature: Poems. South Asia Books, 1992.

Arora, Sudhir K. "Voicing Dalits: The Poetry of Namdeo Dhasal." Indian Literature 53.5 (253 (2009): 220-230. Ashcroft, Bill, Gareth Griffiths, and Helen Tiffin. Key concepts in post-colonial studies. Psychology Press, 1998. Bhaskar, Talluri Mathew. "Sharankumar Limbale"s The Outcaste (Akkarmashi): A Dalit Perspective." Bhaumik, Mahuya. "An Interview with Sharan Kumar Limbale." Writers in Conversation 4.1 (2017).

Dāngale, Arjuna. A Corpse in the well: translations from modern Marathi Dalit autobiographies. Disha Books, 1992.

Dharawadkar, Vinay and Ramanujan A.K. (Ed.), "The Oxford Anthology of Modern Indian Poetry", 1994, Oxford University Press, New Delhi. Dhasal, Namdeo, “A Current of Blood” Translated by Dilip Chitre, 2007, Navayana, New Delhi.

Dhasal, Namdeo, and Dilip Chitre. "Namdeo Dhasal, Poet of the Underworld: Poems, 1972- 2006." Trans, by Dilip

Chitre. Chennai: Navayana Publishing (2007).

Dhasal, Namdeo. "Golpitha." (1975).

Ghosh Anita, "Dalit Feminism: A Psycho-Social Analysis of Indian English Literature," Dalit Literature: A Critical Exploration, 2007, p.48.

J K Lele and R Singh, "Language and Literature of Dalits and Sants: Some Missed Opportunities".

Limbale Sharankumar, "Towards An Aesthetic of Dalit Literature: History, Controversies and Considerations", 2004 New Delhi, Orient Blackswan

Manohar and Rohini Mokashi-Punekar, 2005. Untouchable Saints: An Indian Phenomenon. New Delhi: Manohar.

Narayankar Tejaswini P. "Anger And Protest As The Symbol Of Dalit Feminine Concept", Research Front, ISSN (Print) 2320 - 6446, (Online) 2320 - 8341, pg -7 to 12.

Paswan, Sanjay, and Pramanshi Jaideva.Eds,2002. Encyclopedia of Dalits in India. Vol.II, \& XI Delhi: Kalpaz

Publications.

Patel Neerav,,,What did I do to be so black and blue", Dalit Panther, Ahmedabad.

Sathe, Anna Bhau. "Gold from the Grave." 1992a (1992): 210-15.

Sreenivasan S. (ed), Journal of Literature and Aesthetics, Vol 8, No. 1 and 2, Jan-Dec, 2008, p.274.

Zelliot, E.1992. From Untouchable to Dalit: Essays on Ambedkar Movement. New Delhi:

Zelliot, Eleanor. "Chokhāmeḷā: Piety and Protest." Bhakti Religion in North India: Community Identityand Political Action(1995): 212.

\section{Websites:}

http://www.ambedkar.org/ambcd/38B1.\%20Who\%20were\%20the\%20Shudras\%20P ART\%20I.h to http://www.ambedkar.org/ambcd/39A.Untouchables\%20who\%20were\%20they_why \%20they\% 20became\%20PART\%20I.htm http://www.yale.edu/ynhti/curriculum/units/1991/3/91.03.01.x.html http://www.manushi-india.org 